\title{
Infectious diseases after medical conventions
}

\author{
Rainer Schöfl · Manfred Dierich
}

Received: 10 April 2021 / Accepted: 18 July 2021 / Published online: 17 August 2021

(c) Springer-Verlag GmbH Austria, part of Springer Nature 2021

Dear Editor,

Infection rates resulting from contact during medical conventions are yet unknown. The question raised since the onset of the coronavirus 2019 (COVID-19) pandemic is whether transmission of the coronavirus can be halted by rules of conduct.

The organizers of EndoLinz (a convention focused on gastrointestinal endoscopy) and Ärztetage Velden (a meeting focused on general medicine) addressed the abovementioned issues.

\section{Survey after EndoLinz, a convention held on 30 and 31 January 2020}

The EndoLinz convention was held in the Power Tower in Linz, Austria on 30 and 31 January 2020 and 220 attendees were physically present for $12 \mathrm{~h}$ over 2 days in a hall and jointly consumed a dinner at a restaurant. The attendees were surveyed anonymously 2 weeks later through the online tool SurveyMonkey.

\section{Survey after Ärztetage (congress of physicians) in Velden, 2020}

This convention was held at various sites in Velden, Austria, from 17 to 22 August 2020. In all 350 attendees came together for a maximum of 6 days; no evening event was held. The attendees of the meeting adhered to an extensive COVID-19 prevention program, which

\section{R. Schöfl (ه)}

Ordensklinikum Linz, Linz, Austria

rainer.schoefl@ordensklinikum.at;

rainer.schoefl@24speed.at

R. Schöfl · M. Dierich

Österreichische Akademie der Ärzte, Vienna, Austria included a limited number of attendees, seat tracking, social distancing regulations, obligatory mouth and nose protection, and hand sanitization. The attendees were surveyed anonymously 2 weeks later through the online tool SurveyMonkey.

\section{Results of the survey after EndoLinz 30 and 31 January 2020 (Table 1)}

Of the 220 surveyed attendees 99 (45\%) responded.

Of the 99 respondents 21 (21\%) developed a respiratory infection during the 2 weeks that followed the meeting, on average after 6 days.

- 6 of them had fever,

- 16 had an infection of the upper respiratory tract.

- 2 an infection of the lower respiratory tract.

- 1 had an infection of the upper and lower respiratory tract.

- 1 person came to the convention with symptoms.

- 4 of the 21 ill persons ( $19 \%$ ) had received a flu vaccine during the season.

\section{Results of the survey after Ärztetage Velden, 17-22 August 2020 (Table 1)}

Of 350 surveyed attendees, 206 (59\%) responded.

Out of 206 persons 6 (2.9\%, 55\% were women; the most commonly mentioned age group was $50-60$ years) who responded had been present at the convention for 3-4 days and developed an infection in the 2 weeks that followed the meeting, on average after 7.5 days.

- 2 persons had fever.

- no person had an upper respiratory tract infection.

- 1 had an infection of the lower respiratory tract.

- 1 had an infection of the upper gastrointestinal tract,

- 2 had an infection of the lower gastrointestinal tract. 
Table 1 Results of the surveys EndoLinz and Ärztetage Velden with response rates, infections and national sick leave

\begin{tabular}{|c|c|c|c|c|c|c|}
\hline & Attendees & Respondents & $\begin{array}{l}\text { Respiratory } \\
\text { infections }\end{array}$ & $\begin{array}{l}\text { Gastrointestinal } \\
\text { infections }\end{array}$ & $\begin{array}{l}\text { Total number } \\
\text { of infections }\end{array}$ & $\begin{array}{l}\text { Seasonal rates of absenteeism due to illness } \\
\text { in Austria } \\
(\%)\end{array}$ \\
\hline $\begin{array}{l}\text { EndoLinz } \\
30 \text { and } 31 \text { January } 2020\end{array}$ & 220 & $99(45 \%)$ & 19 & 0 & $21(21 \%)$ & 14 \\
\hline $\begin{array}{l}\text { Ärztetage Velden } \\
17-22 \text { August } 2020\end{array}$ & 350 & $206(59 \%)$ & 1 & 3 & $6(2.9 \%)$ & 6 \\
\hline
\end{tabular}

- No person had a currently positive test for the coronavirus; 1 person had had the coronavirus disease prior to the meeting and tested negative later.

The 14-day disease rates after EndoLinz and Ärztetage Velden were $21 \%$ and $2.9 \%$, respectively (Table 1 ). COVID-19 was not a current issue in Austria during EndoLinz. The first case of COVID-19 in Austria was registered on 17 February and the patient tested positive on 25 February 2020. The Austrian nationwide disease incidence in January 2020 comprised about $14 \%$ of insured persons [1]; the same disease rate of $14 \%$ was recorded in Germany [2]. The flu vaccine rate at the time (19\%) was low even among healthcare personnel.

During Ärztetage Velden in August 2020, the 7-day incidence of the coronavirus disease in Austria was 17-21 new cases per 100,000. In August 2020, about $6 \%$ of insured persons were on sick leave in Austria [1]; the same absenteeism rate of $6 \%$ was noted in Germany [2]. Obviously, the Ärztetage convention benefited from the COVID19 measures with respect to unspecified respiratory infections. The attendees may also have benefited from seasonal factors, such as air temperature or the non-flu season.

A similar survey conducted during the severe acute respiratory syndrome (SARS) epidemic in May 2003 at a fairly large pain convention in Toronto did not address manifest disease but the reasons for attending the meeting despite the attendees' concerns and anxieties [3].

The limitations of the present study are the absence of a direct control group and the inability to verify data quality through complete anonymization and the consequent absence of traceability.
The precautionary measures used at Ärztetage Velden were obviously effective. The data might assist in making decisions as to whether conventions should be planned in times of risk (such as a COVID19 pandemic or a flu epidemic). Alternative forms of advanced education (live streaming, hybrid events, webinars, e-learning modules, etc.) are worthy of consideration. The use of hygiene measures even outside of epidemics appears to have a favorable effect on unspecified infections resulting from human congregations.

Acknowledgement We thank Edda Wiesbauer, Carmen Zavarsky, Nathalie Ubl, and Simon Huber for conducting the survey and Peter Niedermoser for his continuous support.

Conflict of interest R. Schöfl and M. Dierich declare that they have no competing interests.

\section{References}

1. Leoni T, et al. Fehlzeitenreport 2020: Krankheits- und unfallbedingte Fehlzeiten in Österreich; im Auftrag von Bundesarbeitskammer, Wirtschaftskammer, Dachverband der Sozialversicherungsträger; Österreichisches Institut für Wirtschaftsforschung. 2020. https://www. wifo.ac.at/news/news_detail?j-cc-id=1605212015632\&jcc-node=news. Accessed 12 April 2021

2. Badura B, et al., editor. Fehlzeiten-Report 2020. Berlin, Heidelberg: Springer; 2020. https://doi.org/10.1007/9783-662-61524-9.

3. StinsonJ, McCartneyCJ,LeungA, KatzJ.Impact of attending a health care conference in Toronto during the severe acute respiratory syndrome crisis: survey of delegates. Pain Res Manag. 2004;9(3):137-43.

Publisher's Note Springer Nature remains neutral with regard to jurisdictional claims in published maps and institutional affiliations. 